\title{
GUEST PERCEPTION OF SHARIA HOTEL MANAGEMENT \\ IN JEMBER CITY \\ (a Case Study on 'Seven Dream'Sharia Hotel)
}

Hadi Jatmiko(hadijatmiko@unmuhjember.ac.id)

Faculty of Social and Political Science, Hospitality Department, University of MuhammadiyahJember

\begin{abstract}
This study discusseson "Guest Perception of Sharia Hotel Management in Jember City(a Case Study on 'Seven Dream'Sharia Hotel)". It aims to analyze the perceptions of guests to the Shari'ahhotel management based on the accurate data and information represented by the Shari'ahHotel of 'Seven Dream'Jember, the only one hotel in Jember. Respondents in this study are guestsof the Sharia hotel of Seven Dream in Jember by a number of 75 respondents. Data collection techniques in this study use the method of observation, structured interviews, literature study and questionnaire. Data analysis technique uses qualitative descriptive analysis by interpretive approach. Testing the validity of data uses test internal validity by triangulation. Based on the results of data analysis known that consumers in Jember hospitality service users generally perceive good on Shariah-based hotel management. Morefocusing on the domestic touristsequipment, Islamicfacility appearance, Islamic staff appearance, and fast and responsive meeting consumer really needon the Shari'ah-based hotelmanagement.While, focusing on the foreign travelers sympathetic attitude, willingness to help, and readiness in order to provide services inShari'ah-based hotel management in Jember.There is a significant relationship between Shari'ah-based hotel management with the customer satisfaction.
\end{abstract}

Keywords: Perception, Hotel Shariah, Service 
Proceeding ICOGISS 2019

Page 137-145. ISBN: 978-602-6 988-75-1

Web Jurnal Online: jurnal.unmuhjember.ac.id

By: Hadi Jatmiko

Guest Perception Of Sharia Hotel Management In Jember City

\section{INTRODUCTION}

Shariah hotel development began to follow the demands of today's society, and develop Sharia-based hotel unlike develop a conventional hotel. Basically, there are several requirements that must be met, such as the principles of Sharia itself can not be separated from the principles of Islam. Sharia-based hotel development from year to year has increased. This is because the development of the public mindset about Shariah principles, with one of its advantages is to provide security and comfort. Hotel business coverage Sharia is not confined to the Muslim community alone, but is intended for the general public. Terms not much different from management of hotel operations system in general.

One of the Sharia-based hotel in the town of Jember is the Hotel Seven Dream Syariah namely hotels adopt Shari'a into their hotel operations. But until now, the standardization of Syariah standard hotel yet, and yet also be made by the Islamic institutions that are in this country, such as MUI, Ministry of Religious Affairs, as well as by Islamic organizations. But it is not a difficult problem to make some provisions in the hospitality business corresponding to the rules of Sharia.

Based on the background described above, the problem to be examined in this study is "a perception of the sharia hotel management and hotel service systems Seven Dream Sharia as the management of sharia-based hotel"

The purpose of this study to find out: "The perception of the management of the hotel guests sharia and hotel service systems Seven Dream Sharia as the management of Islamicbased hotel".

Outcomes in pThis enelitian form of design management, procedures, policies and services in Islamic-based hotel.

\section{RESEARCH METHODS}

This research uses descriptive technical analysis used to answer the question of how the perception of tourists to the hotel pengeloaan based on Shari'ah: The service and hotel work procedures, whether there are differences in perception of the votes based hotel management of Shari'ah: The service and hotel work procedures, among tourists foreign domestic tourists, and whether there are differences in perception on to the management of Shari'ah-based hotel: Excellent service and hotel work procedures, which are segmented based on demographic characteristics of travelers. For it must first know the average ideal value Medium (M) and standard deviation or standard deviation (SD) based on the maximum and minimum scores obtained from public perception. From these two values can be arranged category of consumer perception into five categories. According Singgarimbun (1989) that the ideal values (M) that can be arranged into five categories, namely the tendency of consumer perception:
a. $\quad M+1 \frac{1}{2}$ SD to the top $=$ Strongly agree
b. $M+1 / 2 S D$ up to $M+1 \frac{1}{2} S D=$ Agree
c. $\mathrm{M}-1 / 2 \mathrm{SD}$ up to $\mathrm{M}+1 / 2 \mathrm{SD}=$ Undecided
d. $\quad M-1 \frac{1}{2} \mathrm{SD}$ up to $\mathrm{M}+1 / 2 \mathrm{SD}=$ Disagree 
e. Down to M-1 $1 / 2 \mathrm{SD}=$ Strongly disagree

As a guideline must first know the ideal lowest score and the highest score of the ideal, then the standard deviation (SD) and average ideally (M) can be calculated as follows:

The average value of the ideal $(\mathrm{M})$ is the maximum score $+1 / 2$ minimum score and standard deviation (SD) is ideally a minimum-score $1 / 6$ score maximum

The scale used in this study were of Rensis Likert Likert scale. This method uses a series of questions to gauge consumer attitudes based on the average response but has a different answer clear enough. Each respondent was asked to provide a statement indicating the level:
a. Strongly agree
b. Agree
c. Doubtful
d. Disagree
e. Strongly disagree

Each answer each given a certain score is 1 to 5 . For the questions are formulated in a positive sentence statement then answer the most support were given the highest score while for the question in the negative sentence statement then answer the questions most do not support given the lowest score. So the lowest value is $1 \times 16=16$, while the highest value is $5 \times 16=80$, if the people do not believe (hesitation) then its value is $3 \times 16=48$, the value of 48 is considered neutral or average looking (M). From each group of the value is the value that is greater than 48 is considered a positive value (support or agree) while the value of smaller than 48 is considered negative means that do not support or agree. With these norms,

Category traveler perception of the perception of tourists to the hotel pengeloaan based on the Shari'a.

\begin{tabular}{cccc}
\hline No. & attitude scale & Category attitude & Score Answer Attitude \\
\hline 1 & 5 & Strongly agree & $65-80$ \\
2 & 4 & Agree & $54-64$ \\
3 & 3 & Doubtful & $43-53$ \\
4 & 2 & Disagree & $33-42$ \\
5 & 1 & Strongly agree & $16-32$ \\
\hline
\end{tabular}

\section{Statistic analysis}

To know whether there is a relationship between factors identified from management of Shari'ah-based hotel: Services and working procedures with a general statement regarding the attitude of people to give satisfaction to the consumer, in penelitian uses quantitative analysis is also often referred to statistical analysis. In analyzing the data herein calculating tool used statistics to calculate the hypothesis that has been set. As for the test or calculate the correlation coefficient between independent variables and the dependent variable statistical Spearman rank test was used. Use of the Spearman rank test based on the type of research that is used. The data obtained in this study are ordinal data, where the data is usually expressed in a kind of relationship which is expressed in classes, eg higher, preferably and so on. According Sugiyono (2003: 4) "ordinal data is data in the form of 
ranking or rating". Siegel (1997: 250) argues that: "Spearman Rank is a measure of association according to the two variables are measured at least in ordinal scale so that objects or individuals being studied can be ranked in two consecutive series". Steps in pengguanaan Spearman rank correlation coefficient according to Siegel (1997: 263) as follows:

a. Give ranking observations on variable $\mathrm{X}$ from 1 to $\mathrm{N}$ large. Also observations on variable $\mathrm{Y}$ from 1 to $\mathrm{N}$.

b. Register $\mathrm{N}$ of the subject. Give each subject's ranking in the variables $\mathrm{X}$ and its rank in the variable $\mathrm{Y}$.

c. Determine the price for each subject by subtracting rank on rank X. Y Multiply the price to determine di2 each subject. Add up the prices di2 to Nth case in order to get the amount.

d. If the same proportion of the numbers in the observations of $\mathrm{X}$ or $\mathrm{Y}$ then used the Spearman rank correlation formula to rank twins.

e. If the subjects were a random sample from a certain population, we can test whether the price rs observations provide indication of an association between variables $\mathrm{X}$ and $\mathrm{Y}$ in the population. The method for doing so depends on the size of N. For $\mathrm{N}$ from 4 to 30, price rs critical to the significance level of 0.05 and 0.01 (tests or side) are presented in the table. For $N \square 10$, the significance of a price by price rs observation can be determined by calculating $\mathrm{t}$ correspond to the price and then determine the significance of that price.

Spearman rank correlation formula as follows: 
Proceeding ICOGISS 2019

Page 137-145. ISBN: 978-602-6 988-75-1

Web Jurnal Online: jurnal.unmuhjember.ac.id

By: Hadi Jatmiko

Guest Perception Of Sharia Hotel Management In Jember City

formula I

$$
r_{s=1}-\frac{6 \sum_{i=1}^{N} d_{i}^{2}}{N^{3}-N}
$$

(Siegel, 1997: 253)

Information:

$$
\begin{aligned}
& r s \text { Spearman rank correlation coefficient }= \\
& d i 2=\text { Squared difference at each rank } \\
& \mathrm{N}=\text { number of respondents }
\end{aligned}
$$

The above formula can be used if the rank twins are not more than one, so consequently rs can be ignored, but the number of large twin rank value then can use the following formula:

formula II

$$
r s=\frac{\sum x^{2}+\sum y^{2}-\sum d_{i}^{2}}{2 \sqrt{2} \sum y^{2}}
$$

(Siegel, 1997: 256)

Information:

$$
\begin{aligned}
& r s \text { Spearman rank correlation coefficient }= \\
& \square x 2=\text { The amount of variation in the } \mathrm{X} \\
& \square y 2=\text { The amount of variation in the } \mathrm{Y} \\
& \square d i 2=\text { Sum of the squared differences of each pair of rank }
\end{aligned}
$$

To find the price of $\mathrm{x} 2$ and $\mathrm{y} 2$ use the following formula: 
Proceeding ICOGISS 2019

Page 137-145. ISBN: 978-602-6 988-75-1

Web Jurnal Online: jurnal.unmuhjember.ac.id

By: Hadi Jatmiko

Guest Perception Of Sharia Hotel Management In Jember City

formula III

$$
\begin{aligned}
& \square \mathrm{x} 2=\frac{N^{3}-N}{12}-\sum T_{x} \\
& \square \mathrm{y} 2=\frac{N^{3}-N}{12}-\sum T_{y}
\end{aligned}
$$

(Siegel, 1997: 257)

Information:

$$
\begin{aligned}
& \square x 2=\text { The amount of variation in the } \mathrm{X} \\
& \square y 2=\text { The amount of variation in the } \mathrm{Y} \\
& \square T x=\text { Number of variable frequency twin } \mathrm{X} \\
& \square T y=\text { Number of twin frequencies of variable } \mathrm{Y} \\
& \mathrm{N}=\text { number of respondents }
\end{aligned}
$$

While provisions for seeking price $\mathrm{T}$ for the variables $\mathrm{X}$ and $\mathrm{Y}$ use the following formula:

formula IV

$$
\begin{aligned}
& T_{x}=\frac{t^{3}-t}{12} \\
& T y=\frac{t^{3}-t}{12}
\end{aligned}
$$

(Siegel, 1997: 256)

Information:

$\mathrm{t}=$ the number of twins in a single rank ranking

$T x=$ Frequency of twin variable $\mathrm{X}$

$T y=$ Frequency of twin variable $\mathrm{Y}$

If rs $\square$ rs table, the null hypothesis (Ho) is rejected and the hypothesis (Ha) is accepted.

If, rs $\square$ rs table, the null hypothesis (Ho) is received and the hypothesis (ha) was rejected.

Furthermore, to test the significance of the use of twin rank formula for the sampl

$(\mathrm{N})$ is more than $10(\mathrm{~N}>10)$, it can be tested using the t-test formula as follows:

formula $\mathrm{V}$

$$
\mathrm{t}=r s \sqrt{\frac{N 2}{1 r_{s}^{2}}}
$$

(Siegel, 1997: 263)

Information:

$$
\begin{aligned}
& \mathrm{t}=\text { magnitude } \mathrm{t} \text { test } \\
& r s \text { Spearman rank coefficient }= \\
& N=\text { Number of respondents } \\
& R S 2=\text { Squared Spearman rank correlation coefficient }
\end{aligned}
$$

In this research hypothesis testing, the level of significance of $\square=0.05$, which means that the tests used for testing this hypothesis have the possibility of error of 5\% in rejecting or accepting Ha with a confidence level of $95 \%$. To capture the conclusion of the calculation $t$ consulted with critical values with the following criteria:

1) If $\mathrm{t}$ arithmetic $\geq \mathrm{t}$ table, the null hypothesis (Ho) is rejected and the alternative hypothesis $(\mathrm{Ha})$ is accepted, so there is a significant relationship between factors 
Proceeding ICOGISS 2019

Page 137-145. ISBN: 978-602-6 988-75-1

Web Jurnal Online: jurnal.unmuhjember.ac.id

By: Hadi Jatmiko

Guest Perception Of Sharia Hotel Management In Jember City

identified from questionable job-related behavior with a general statement regarding the attitude of people to give satisfaction to the consumer.

2) If $\mathrm{t} \leq \mathrm{t}$ table, the null hypothesis (Ho) is received and the alternative hypothesis (Ha) is rejected, so there is no significant relationship between factors identified from questionable job-related behavior with a general statement regarding the attitude of people to give satisfaction to the consumer.

The conclusion reached by mengguanakan correlation coefficient to determine the level of relationship between variables according Sugiyono (2003: 149), namely:

0.000 to 0.199 : very low correlation

0.200 to 0.399 : Low relationship

0.400 to 0.599 : a connection was

0.600 to 0.799 : strong relationship

0.800 to 1.000 : very strong relationship

withdrawal ConclusionIn the final stage of research it is necessary to draw conclusions from the results of the investigation, that conclusion is based on data and formulations that have been analyzed to solve the problem raised. In conclusion use deductive method, which means drawing conclusions from things that are generally based on all the things that are special. Once the required data collected then analyzed to answer the research problem, namely how the perception of tourists to the hotel pengeloaan based on Shari'ah: The service and hotel work procedures 
Proceeding ICOGISS 2019

Page 137-145. ISBN: 978-602-6 988-75-1

Web Jurnal Online: jurnal.unmuhjember.ac.id

By: Hadi Jatmiko

Guest Perception Of Sharia Hotel Management In Jember City

\section{RESULTS AND DISCUSSION}

Hotel Seven Dream is one of the hotels in Jember are beginning to apply Shari'ahbased hotel management. This study examines consumer perceptions of Shari'ah-based hotel management and hubungannnya to customer satisfaction. The results showed that pelitian relating to consumer perceptions of shari'a-based hotel management obtained a description that in general consumers assess Shari'ah-based hotel management is good. The good management of Shariah-based hotel in Jember can be seen fromHotel Seven Dream Sharia has the latest equipment / date, physical facilities Hotel Seven Dream Sharia has the appeal of Islamic, employees of Hotel Seven Dream Syariah groomed and un-Islamic, the appearance of the facility Hotel Seven Dream Sharia according to the type of services that are Islamic, Hotel Seven Dream Syariah provide services timely, Hotel Seven Dream Sharia to be sympathetic to the problems of customers, Hotel Seven Dream Syariah make every note and service with accurate, the Hotel Seven Dream Sharia is always ready to provide services, the Hotel Seven Dream Syariah always willing to help the customers, and the Hotel Seven Dream Sharia respond to any customer requests quickly.

In general, it can be stated that the domestic tourists more focused on aspects of physical evidence and the reliability of the hotel, while foreign tourists focus on the aspect of empathy and responsiveness of the hotel. Such conditions will certainly require serious attention from the hotel management. thus, Seven Dream Hotel Syariah really able to provide Shari'ah-based hotel management concept that is more optimal.

\section{CONCLUSION}

Based on the analysis and discussion, it can take several conclusions, as follows:

1. Consumers in Jember hospitality service users generally perceive good on shari'a-based hotel management through the study at the Hotel Seven Dream Sharia in Jember. Focusing more on the domestic touristsequipment, facilities Islamic appearance, and speed in meeting consumer demand in the management Shari'ah-based hotel, while focusing on the foreign travelers sympathetic attitude, willingness to help, and readiness to provide services in management Shari'ah-based hotel.

2. There is a significant relationship between Shari'ah-based hotel management with customer satisfaction. 
Proceeding ICOGISS 2019

Page 137-145. ISBN: 978-602-6 988-75-1

Web Jurnal Online: jurnal.unmuhjember.ac.id

By: Hadi Jatmiko

Guest Perception Of Sharia Hotel Management In Jember City

\section{REFERENCE}

Agusnawar, 2002. Introduction to Operations Office Home Hotel. PT. Percha, Jakarta

Darsono A. 2001. Office Home Hotel. PT.Gramedia Widiasarana Indonesia: Jakarta

Handoko, 2000. Personnel Management and Human Resources. BPFE: Yogyakarta

Rangkuti, 2001. Dissecting SWOT Analysis Technique Business Case. Jakarta: Gramedia Pustaka Utama.

Soekadijo. RG 2000. Anatomy of Tourism. Jakarta: PT Gramedia Pustaka General.

Soekresno, 2001. Management Food \& Beverage Service. PT. Gramedia Pustaka Utama

Sugiarto, 1996. Introduction Accommodation and Restaurants. PT. Gramedia Pustaka Utama: Jakarta

Sugiharto, 2003. Introduction Accommodation and Restoran.Gramedia Pustaka Utama , Ir, MM. 1997. Operations Home Office. PT. Gramedia Pustaka Utama: Jakarta.

Swastha, 1997. Modern Marketing Management. The fifth edition, Yogyakarta: Liberty.

Tjiptono, 2001. "Marketing Strategy". The second edition, Yogyakarta: Andi

Wahab, Salah. 1997. Tourism Marketing. Jakarta: PT. Pradya Paramitha.

Yoeti, Oka. 1996. Tourism Marketing, Bandung: Space Bandung. 